\title{
New CVD Precursors Capable of Depositing Copper Metal under Mixed $\mathrm{O}_{2} /$ Ar Atmosphere
}

\author{
Eddy Lay, Yi-Hwa Song, Yuan-Chieh Chiu, Yang-Miin Lin, and Yun Chi* \\ Department of Chemistry, National Tsing Hua University, Hsinchu 30013, Taiwan
}

Arthur J. Carty*

Steacie Institute for Molecular Sciences, National Research Council Canada, 100 Sussex Drive, Ottawa, Ontario K1A OR6, Canada.

\author{
Shie-Ming Peng and Gene-Hsiang Lee \\ Department of Chemistry and Instrumentation Center, National Taiwan University, Taipei 10764, \\ Taiwan \\ Received May 25, 2005
}

\begin{abstract}
Volatile low-melting Cull metal complexes $\mathrm{Cu}\left[\mathrm{OC}\left(\mathrm{CF}_{3}\right)_{2} \mathrm{CH}_{2} \mathrm{C}(\mathrm{Me})=\mathrm{NMe}\right]_{2}(4)$ and $\mathrm{Cu}\left[\mathrm{OC}\left(\mathrm{CF}_{3}\right)_{2} \mathrm{CH}_{2} \mathrm{CHMeNHMe}_{2}\right.$ (5) were synthesized and characterized by spectroscopic methods. A single-crystal $\mathrm{X}$-ray diffraction study on complex 4 shows the anticipated $\mathrm{N}_{2} \mathrm{O}_{2}$ square-planar geometry with the imino alcoholate ligand arranged in the all-trans orientation. In contrast, a highly distorted $\mathrm{N}_{2} \mathrm{O}_{2}$ geometry with a dihedral angle of $33^{\circ}$ was observed for complex 5 , suggesting that the fully saturated amino alcoholate ligand produces a much greater steric congestion around the metal ion. Metal CVD experiments were conducted, showing that both complexes, $\mathbf{4}$ and $\mathbf{5}$, are capable of depositing copper metal at temperatures of $275-300^{\circ} \mathrm{C}$ using an inert argon carrier gas mixed with low concentrations $(2-8 \%)$ of $\mathrm{O}_{2}$. The best copper thin film showed a purity of $\sim 96$ at. \% and a resistivity of $2.11 \mu \Omega \mathrm{cm}$ versus that of the bulk standard $(1.7 \mu \Omega \mathrm{cm})$, as revealed by XPS and four-point probe analyses, respectively. We speculate that the low concentration of $\mathrm{O}_{2}$ promotes partial ligand oxidation, thus releasing the reduced copper on the substrate and affording the high-purity copper deposit.
\end{abstract}

Copper-based metallization has been introduced into leading-edge microelectronic industries because of its promising physical properties, such as lower resistivity, improved electromigration resistance, and increased resistance to stressinduced formation of voids caused by a higher melting point for copper. ${ }^{1}$ The deposition of copper metal films via MOCVD have been achieved by using $\mathrm{Cu}^{\mathrm{II}}$ complexes, such as $\mathrm{Cu}(\mathrm{acac})_{2}$ or $\mathrm{Cu}(\mathrm{hfac})_{2}$ where acac $=$ acetylacetonate and hfac $=$ hexafluoroacetylacetonate. ${ }^{2}$ For example, with $\mathrm{Cu}-$ $(\mathrm{hfac})_{2}$ high-purity copper metal can be obtained at relatively

* To whom correspondence should be addressed. Fax: (886) 3 5720864. E-mail: ychi@mx.nthu.edu.tw.

(1) Griffin, G. L.; Maverick, A. W. In The Chemistry of Metal CVD; Kodas, T. T., Hampden-Smith, M. J., Ed.; VCH: Wienheim, Germany, 1994; Chapter 4. (b) Rickerby, J.; Steinke, J. H. G. Chem. Rev. 2002, 102, 1525. (c) Vertoprakhov, V. N.; Krupoder, S. A. Russ. Chem. Rev. 2000, 69, 1057. (d) Doppelt, P. Coord. Chem. Rev. 1998, $178-$ 180, 1785 .

7226 Inorganic Chemistry, Vol. 44, No. 20, 2005 low temperatures in the presence of an external reducing agent, $\mathrm{H}_{2}$. This deposition reaction is best represented by the following transformation

$$
\mathrm{Cu}(\mathrm{hfac})_{2}+\mathrm{H}_{2} \rightarrow \mathrm{Cu}_{(\mathrm{s})}+2(\mathrm{hfac}) \mathrm{H}
$$

Upon removal of the external reducing carrier gas, $\mathrm{H}_{2}, \mathrm{Cu}^{\mathrm{II}}$ diketonate source reagents leave an excess of carbon and other contaminants on the thin film because of unwanted heat-induced ligand fragmentation. ${ }^{3}$

(2) Armitage, D. N.; Dunhill, N. I.; West, R. H.; Williams, J. O. J. Cryst. Growth 1991, 108, 683. (b) Nuesca, G. M.; Kelber, J. A. Thin Solid Films 1995, 262, 224. (c) Borgharkar, N. S.; Griffin, G. L. J. Electrochem. Soc. 1998, 145, 347. (d) Utriainen, M.; KrogerLaukkanen, M.; Johansson, L.-S.; Niinisto, L. Appl. Surf. Sci. 2000 157, 151.

(3) Temple, D.; Reisman, A. J. Electrochem. Soc. 1989, 136, 3525. (b) Kaloyeros, A. E.; Feng, A.; Garhart, J.; Brooks, K. C.; Ghosh, S. K.; Saxena, A. N.; Luehrs, F. J. Electron. Mater. 1990, 19, 271. 
On the other hand, $\mathrm{Cu}^{\mathrm{I}}$ complexes have also been developed, for which the best known reagents are the commercially available (hfac) $\mathrm{CuL}$, where $\mathrm{L}=$ trimethylvinylsilane ${ }^{4}$ or 2-methyl-1-hexen-3-yne. ${ }^{5}$ These have been used to deposit high-purity copper thin films in the absence of $\mathrm{H}_{2}$ gas, through a well-established process involving thermally induced disproportionation

$$
2(\text { hfac }) \mathrm{CuL} \rightarrow \mathrm{Cu}_{(\mathrm{s})}+2 \mathrm{~L}+\mathrm{Cu}(\mathrm{hfac})_{2}
$$

In general, high-quality copper metal thin films can be easily obtained using these $\mathrm{Cu}^{\mathrm{I}}$ precursors. However, it is worth noting that these complexes are thermally unstable and begin to decompose at elevated temperatures. Thus, these $\mathrm{Cu}^{\mathrm{I}}$ complexes need to be stored in a refrigerator or in the presence of a chemical stabilizer, for example with an excess of the $\pi$-donor ligand, to improve the thermal stability. ${ }^{6}$ These precautions are undesirable for CVD processes that require elevated temperatures, faster vapor transport, and higher partial pressures of the copper CVD source reagent.

In this paper, we introduce a new series of $\mathrm{Cu}^{\mathrm{II}} \mathrm{CVD}$ precursors, in which the copper metal is chelated by two fluorinated imino alcoholate or amino alcoholate ligands. These precursors exhibit several practical advantages such as easy accessibility and higher volatility as well as the thermal stability attributed to the $\mathrm{Cu}^{\mathrm{II}}$ systems. Moreover, we also discovered that these precursors can be used to deposit high-purity copper films in the presence of a low concentration of $\mathrm{O}_{2}$ carrier gas mixed in argon, rather than the typical reductive environment applied to the traditional $\mathrm{Cu}^{\mathrm{II}} \beta$-diketonate source complexes. . $^{2,3,7}$

\section{Experimental Section}

General Information and Materials. Mass spectra were obtained on a JEOL SX-102A instrument operating in electronimpact (EI) mode. The thermogravimetric analyses (TGA) were recorded on a Seiko TG/DTA 300 instrument under an atmospheric pressure of argon with a standard flow rate of $100 \mathrm{~cm}^{3} \mathrm{~min}^{-1}$ and a heating rate of $10{ }^{\circ} \mathrm{C} \mathrm{min}^{-1}$. Microanalyses were carried out at the NSC Regional Instrumentation Center at National Chiao Tung University, Hsinchu, Taiwan. ${ }^{1} \mathrm{H}$ and ${ }^{13} \mathrm{C}$ NMR spectra were recorded on Varian Mercury-400 instruments; chemical shifts are quoted with respect to $\mathrm{CDCl}_{3}$ for ${ }^{1} \mathrm{H}$ and ${ }^{13} \mathrm{C} \mathrm{NMR}$ data,

(4) Girolami, G. S.; Jeffries, P. M.; Dubois, L. H. J. Am. Chem. Soc. 1993, 115, 1015. (b) Hampden-Smith, M. J.; Kodas, T. Polyhedron 1995, 14, 699. (c) Jain, A.; Kodas, T. T.; Corbitt, T. S.; HampdenSmith, M. J. Chem. Mater. 1996, 8, 1119. (d) ter Heerdt, M. L. H.; van der Put, P. J.; Schoonman, J. Chem. Vap. Deposition 2001, 7, 199. (e) Naik, M. B.; Gill, W. N.; Wentorf, R. H.; Reeves, R. R. Thin Solid Films 1995, 262, 60. (f) Doppelt, P. Microelectron. Eng. 1997, 37-38, 89. (g) Cavallotti, C.; Gupta, V.; Sieber, C.; Jensen, K. F. Phys. Chem. Chem. Phys. 2003, 5, 2818.

(5) Joulaud, M.; Angekort, C.; Doppelt, P.; Mourier, T.; Mayer, D. Microelectron. Eng. 2002, 64, 107. (b) Chen, T.-Y.; Vaissermann, J.; Ruiz, E.; Senateur, J. P.; Doppelt, P. Chem. Mater. 2001, 13, 3993.

(6) Norman, J. A. T.; Robert, D. A.; Hochberg, A. K.; Smith, P.; Peterson, G. A.; Parmeter, J. E.; Apblett, C. A.; Omstead, T. R. Thin Solid Films 1995, 262, 46. (b) Park, M.-Y.; Son, J.-H.; Rhee, S.-W. J. Mater. Res. 1999, 14, 975.

(7) Devi, A.; Goswami, J.; Lakshmi, R.; Shivashankar, S. A.; Chandrasekaran, S. J. Mater. Res. 1998, 13, 687. (b) Bakovets, V. V.; Levashova, T. M.; Dolgovesova, I. P.; Maksimovskii, E. A. Inorg. Mater. 2005, 41, 19. respectively. All reactions were performed under $\mathrm{N}_{2}$ using anhydrous solvents or solvents treated with an appropriate drying reagent.

The $\mathrm{Cu}$ metal thin films were studied using an X-ray diffractometer (XRD) with $\mathrm{Cu} \mathrm{K} \alpha$ radiation. Scanning electron microscopy (SEM) images were recorded on a Hitachi S-4000 system to study the surface morphology. The resistivities were measured using a four-point probe method at room temperature, for which the instrument is assembled using a Keithley 2182 nanovoltmeter and a Keithley 2400 constant current source. The composition of the thin film was determined by X-ray photoelectron spectroscopy (XPS) utilizing a Physical Electronics PHI 1600 system with an $\mathrm{Al} / \mathrm{Mg}$ dual anode $\mathrm{X}$-ray source. The surface composition in atom percent was measured from XPS spectra collected after 1-2 min sputtering with argon at $4 \mathrm{keV}$ until a constant composition was obtained.

Synthesis of 1. Hexafluoroacetone trihydrate (25 g, $113.6 \mathrm{mmol})$ in $90 \mathrm{~mL}$ of acetone was charged into a $160 \mathrm{~mL}$ stainless steel autoclave. The autoclave was slowly heated to $140{ }^{\circ} \mathrm{C}$ and maintained at that temperature for $84 \mathrm{~h}$, giving a pale yellow solution with a small amount of a brown precipitate. The solution was then filtered, treated with anhydrous $\mathrm{MgSO}_{4}$, and concentrated on a rotary evaporator. The oily residue was purified by reduced pressure distillation $\left(2\right.$ Torr, $\left.32{ }^{\circ} \mathrm{C}\right)$, giving $21.1 \mathrm{~g}$ of the colorless product, $\left(\mathrm{CF}_{3}\right)_{2} \mathrm{C}(\mathrm{OH}) \mathrm{CH}_{2} \mathrm{COMe}(1,94.1 \mathrm{mmol}, 83 \%)$.

Spectral Data of 1. ${ }^{1} \mathrm{H}$ NMR $\left(400 \mathrm{MHz}, \mathrm{CDCl}_{3}, 298 \mathrm{~K}\right): \delta$ $6.71(\mathrm{~s}, 1 \mathrm{H}, \mathrm{OH}), 2.93$ (s, 2H, $\left.\mathrm{CH}_{2}\right), 2.33$ (s, 3H, Me).

Synthesis of 2. A $100 \mathrm{~mL}$ flask was charged with $3.5 \mathrm{~g}$ montmorillonite K10, $30 \mathrm{~mL}$ of chloroform, $12.3 \mathrm{~g}$ of ligand $\mathbf{1}$ (55 $\mathrm{mmol}$ ), and $5.0 \mathrm{~g}$ of methylamine $(66 \mathrm{mmol}$, as $40 \%$ methanol solution). The mixture was refluxed for $72 \mathrm{~h}$ under a $\mathrm{N}_{2}$ atmosphere. The montmorillonite $\mathrm{K} 10$ was then removed by filtration; the filtrate was dried over anhydrous $\mathrm{MgSO}_{4}$ and concentrated on a rotary evaporator. The resulting oily liquid was purified by reduced pressure distillation $\left(2.3\right.$ Torr, $38{ }^{\circ} \mathrm{C}$ ), giving $10.8 \mathrm{~g}$ of colorless $\left(\mathrm{CF}_{3}\right)_{2} \mathrm{C}(\mathrm{OH}) \mathrm{CH}_{2} \mathrm{CMe}(=\mathrm{NMe})(2,45.6 \mathrm{mmol}, 83 \%)$.

Spectral Data of 2. ${ }^{1} \mathrm{H}$ NMR $\left(400 \mathrm{MHz}, \mathrm{CDCl}_{3}, 298 \mathrm{~K}\right): \delta$ 3.12 (s, 3H, NMe), 2.67 (s, 2H, $\left.\mathrm{CH}_{2}\right), 1.95$ (s, 3H, Me). ${ }^{13} \mathrm{C} \mathrm{NMR}$ $\left(100 \mathrm{MHz}, \mathrm{CDCl}_{3}, 298 \mathrm{~K}\right): \delta 171.2$ (s, 1C, CN), 123.2 (q, 1C, ${ }^{1} J_{\mathrm{CF}}=287 \mathrm{~Hz}, \mathrm{CF}_{3}$ ), 76.8 (septet, $1 \mathrm{C},{ }^{2} J_{\mathrm{CF}}=29 \mathrm{~Hz}, \mathrm{CO}$ ), 36.7 (1C, $\mathrm{NMe}), 32.9\left(1 \mathrm{C}, \mathrm{CH}_{2}\right), 19.2(1 \mathrm{C}, \mathrm{Me})$.

Synthesis of 3. Lithium aluminum hydride $(1.52 \mathrm{~g}, 40 \mathrm{mmol})$ was suspended in diethyl ether (20 mL). Compound 2 (4.74 g, 20 mmol) was added dropwise to this, and the mixture was stirred at room temperature for $3 \mathrm{~h}$. Water $(2 \mathrm{~mL})$ was then injected dropwise to quench the reaction. The resulting white emulsion was treated with saturated $\mathrm{NH}_{4} \mathrm{Cl}_{(\mathrm{aq})}(3 \mathrm{~mL})$, and the organic layer was extracted with diethyl ether, dried over anhydrous $\mathrm{MgSO}_{4}$, filtered, and concentrated on a rotary evaporator. Reduced pressure distillation at 2.2 Torr and $44{ }^{\circ} \mathrm{C}$ gave $3.2 \mathrm{~g}$ of the colorless liquid ligand $\left(\mathrm{CF}_{3}\right)_{2} \mathrm{C}(\mathrm{OH}) \mathrm{CH}_{2} \mathrm{CHMeNHMe}(3,13.4 \mathrm{mmol}, 67 \%)$.

Spectral Data of 3. ${ }^{1} \mathrm{H}$ NMR $\left(400 \mathrm{MHz}, \mathrm{CDCl}_{3}, 298 \mathrm{~K}\right): \delta$ $3.14(\mathrm{~m}, 1 \mathrm{H}, \mathrm{CH}), 2.40(\mathrm{~s}, 3 \mathrm{H}, \mathrm{NMe}), 1.92\left(\mathrm{dd}, 1 \mathrm{H},{ }^{3} J_{\mathrm{HH}}=15.2\right.$ $\left.\mathrm{Hz}, 2.8 \mathrm{~Hz}, \mathrm{CH}_{2}\right), 1.73\left(\mathrm{~m}, 1 \mathrm{H}, \mathrm{CH}_{2}\right), 1.17\left(\mathrm{~d}, 2 \mathrm{H},{ }^{3} J_{\mathrm{HH}}=6.4 \mathrm{~Hz}\right.$, $\left.\mathrm{CH}_{3}\right) .{ }^{13} \mathrm{C} \mathrm{NMR}\left(100 \mathrm{MHz}, \mathrm{CDCl}_{3}, 298 \mathrm{~K}\right): \delta 124.1$ (q, $1 \mathrm{C},{ }^{1} J_{\mathrm{CF}}$ $\left.=288 \mathrm{~Hz}, \mathrm{CF}_{3}\right), 123.2\left(\mathrm{q}, 1 \mathrm{C},{ }^{1} J_{\mathrm{CF}}=288 \mathrm{~Hz}, \mathrm{CF}_{3}\right), 76.7$ (septet, $\left.1 \mathrm{C},{ }^{2} J_{\mathrm{CF}}=29 \mathrm{~Hz}, \mathrm{CO}\right), 52.0(1 \mathrm{C}, \mathrm{CH}), 31.9\left(1 \mathrm{C}, \mathrm{CH}_{2}\right), 31.6(1 \mathrm{C}$, $\mathrm{NMe}), 20.0$ (1C, Me).

Synthesis of 4. Sodium hydride $(0.29 \mathrm{~g}, 12 \mathrm{mmol})$ was suspended in $25 \mathrm{~mL}$ of THF. Compound $2(2.37 \mathrm{~g}, 10 \mathrm{mmol})$ in $25 \mathrm{~mL}$ of THF was added dropwise to this. The mixture was stirred for $2 \mathrm{~h}$ until evolution of gas had ceased. The solution was filtered to remove the unreacted $\mathrm{NaH}$, and the filtrate was transferred into a $100 \mathrm{~mL}$ flask containing a suspension of $\mathrm{CuCl}_{2}(0.68 \mathrm{~g}, 5.1 \mathrm{mmol})$ 
Lay et al.

in THF $(25 \mathrm{~mL})$. Th mixture was stirred for $12 \mathrm{~h}$, giving a blue solution with an off-white $\mathrm{NaCl}$ precipitate. After the solution was filtered and evaporated to dryness, vacuum sublimation (350 mTorr, $100{ }^{\circ} \mathrm{C}$ ) yielded $1.97 \mathrm{~g}$ of a light purple solid, $\mathrm{Cu}\left[\mathrm{OC}\left(\mathrm{CF}_{3}\right)_{2} \mathrm{CH}_{2} \mathrm{C}\right.$ $(\mathrm{Me})=\mathrm{NMe}_{2}(4,3.7 \mathrm{mmol}, 72 \%)$. Single crystals suitable for X-ray diffraction studies were obtained by diffusion of hexane into a solution of $\mathrm{CH}_{2} \mathrm{Cl}_{2}$ at room temperature.

Spectral Data of 4. MS (EI, $m / z, L=\mathrm{C}_{7} \mathrm{H}_{8} \mathrm{~F}_{6} \mathrm{NO}$ ), observed (actual) [assignment]: 535 (535) [ $\left.\mathrm{CuL}_{2}\right], 466(466)\left[\mathrm{CuL}_{2}-\mathrm{CF}_{3}\right]$, 369 (369) $\left[\mathrm{CuL}_{2}-\mathrm{C}_{3} \mathrm{~F}_{6} \mathrm{O}\right.$ ], 300 (299) [CuL], 236 (236) [L], 230 (230) $\left[\mathrm{CuL}-\mathrm{CF}_{3}\right], 134$ (133) $\left[\mathrm{CuL}-\mathrm{C}_{3} \mathrm{~F}_{6} \mathrm{O}\right], 70$ (70) $[\mathrm{L}-$ $\mathrm{C}_{3} \mathrm{~F}_{6} \mathrm{O}$ ]. Anal. Calcd for $\mathrm{C}_{14} \mathrm{H}_{16} \mathrm{CuF}_{12} \mathrm{~N}_{2} \mathrm{O}_{2}$ : C, 31.38; H, 3.01; N, 5.23. Found: C, 31.51; H, 3.33; N, 5.01.

Synthesis of 5. Procedures identical to those employed to prepare 4 were followed, using $0.288 \mathrm{~g}$ of sodium hydride (12 mmol), 2.39 $\mathrm{g}$ of ligand $3(10 \mathrm{mmol})$, and $0.68 \mathrm{~g}$ of $\mathrm{CuCl}_{2}(5.1 \mathrm{mmol})$. After the THF solvent was removed, vacuum sublimation $(250 \mathrm{mTorr}$, $\left.85{ }^{\circ} \mathrm{C}\right)$ yielded $1.92 \mathrm{~g}$ of a light purple solid, $\mathrm{Cu}\left[\mathrm{OC}\left(\mathrm{CF}_{3}\right)_{2} \mathrm{CH}_{2}-\right.$ $\mathrm{CHMeNHMe}_{2}(\mathbf{5}, 3.6 \mathrm{mmol}, 70 \%)$. Single crystals suitable for $\mathrm{X}$-ray diffraction studies were obtained by diffusion of hexane into a solution of $\mathrm{CH}_{2} \mathrm{Cl}_{2}$ at room temperature.

Spectral Data of 5. MS (EI, m/z, L $=\mathrm{C}_{7} \mathrm{H}_{10} \mathrm{~F}_{6} \mathrm{NO}$ ), observed (actual) [assignment]: 539 (539) $\left[\mathrm{CuL}_{2}\right], 375$ (373) $\left[\mathrm{CuL}_{2}-\right.$ $\mathrm{C}_{3} \mathrm{~F}_{6} \mathrm{O}$ ], 302 (301) [CuL], 238 (238) [L], 134 (135) [CuL - $\mathrm{C}_{3} \mathrm{~F}_{6} \mathrm{O}$ ], 71 (72) $\left[\mathrm{L}-\mathrm{C}_{3} \mathrm{~F}_{6} \mathrm{O}\right]$. Anal. Calcd for $\mathrm{C}_{14} \mathrm{H}_{20} \mathrm{CuF}_{12} \mathrm{~N}_{2} \mathrm{O}_{2}$ : C, 31.15; H, 3.73; N, 5.19. Found: C, 31.12; H, 3.91; N, 5.38.

X-ray Structural Determination. Single-crystal X-ray diffraction data were recorded on a Bruker SMART CCD diffractometer using Mo $\mathrm{K} \alpha$ radiation $(\lambda=0.71073 \AA)$. The data collection was executed using the SMART program. Cell refinement and data reduction were made with the SAINT program. The structure was determined using the SHELXTL/PC program, and the refinement was made using full-matrix least-squares refinement. All nonhydrogen atoms were refined anisotropically, for which hydrogen atoms were placed at the calculated positions and included in the final stage of refinements with fixed positional parameters. The crystallographic refinement parameters of complexes $\mathbf{4}$ and $\mathbf{5}$ are summarized in Table 1, while the selective bond distances and angles of these complexes are listed in Tables 2 and 3, respectively.

CVD Procedures. The deposition of copper was carried out with a homemade vertical cold-wall reactor as described in previous studies. ${ }^{8}$ The working pressure during deposition was maintained at $\sim 1.5$ Torr with a typical background pressure of $1 \times 10^{-3}$ Torr. The mixed argon gas containing 2 and $8 \% \mathrm{O}_{2}$ was purchased from a local supplier (Chiah Lung Enterprise Co., Ltd. Hsinchu, Taiwan), and their compositional ratios were checked by gas chromatography. The flow rate of the carrier gas was adjusted to $10-20 \mathrm{sccm}$, and the carrier gas was immediately turned off at the end of the deposition reaction to avoid the oxidation of the as-deposited copper thin film. The carrier gas was then introduced through the sidearm of the sample reservoir, which was loaded with $\sim 250 \mathrm{mg}$ of the source reagent for each CVD experiment. The typical deposition time was adjusted to $10-15 \mathrm{~min}$, while the sample reservoir temperature was reduced to $50{ }^{\circ} \mathrm{C}$ and the deposition time was reduced to $3 \mathrm{~min}$ for experiments using source reagent $\mathrm{Cu}(\mathrm{hfac})_{2}$ because of its higher vapor pressure. Before each experiment, the Si wafers were cleaned using a dilute HF solution, which was followed by washing with deionized water and acetone in sequence and drying under nitrogen.

(8) Yu, H.-L.; Chi, Y.; Liu, C.-S.; Peng, S.-M.; Lee, G.-H. Chem. Vap. Deposition 2001, 7, 245. (b) Lai, Y.-H.; Chou, T.-Y.; Song, Y.-H.; Liu, C.-S.; Chi, Y.; Carty, A. J.; Peng, S.-M.; Lee, G.-H. Chem. Mater. 2003, 15, 2454.
Table 1. X-ray Structural Data for Complexes 4 and 5

\begin{tabular}{|c|c|c|}
\hline & 4 & 5 \\
\hline formula & $\mathrm{C}_{14} \mathrm{H}_{16} \mathrm{CuF}_{12} \mathrm{~N}_{2} \mathrm{O}_{2}$ & $\mathrm{C}_{14} \mathrm{H}_{20} \mathrm{CuF}_{12} \mathrm{~N}_{2} \mathrm{O}_{2}$ \\
\hline mol wt & 535.83 & 539.86 \\
\hline temp & $150(1) \mathrm{K}$ & 295(2) K \\
\hline crys syst & orthorhombic & monoclinic \\
\hline space group & Pna $2_{1}$ & $P 2 / n$ \\
\hline$a(\AA)$ & $19.8983(13)$ & $12.0784(8)$ \\
\hline$b(\AA)$ & $8.8891(6)$ & $7.0847(5)$ \\
\hline$c(\AA)$ & $10.7143(7)$ & $13.1862(9)$ \\
\hline$\beta$ (deg) & & $111.190(1)$ \\
\hline$V\left(\AA^{3}\right)$ & $1895.1(2)$ & $1052.1(1)$ \\
\hline$Z$ & 4 & 2 \\
\hline$D_{\mathrm{c}}\left(\mathrm{mg} \mathrm{m}^{-3}\right)$ & 1.878 & 1.704 \\
\hline$F(000)$ & 1068 & 542 \\
\hline cryst size $\left(\mathrm{mm}^{3}\right)$ & $0.40 \times 0.25 \times 0.25$ & $0.28 \times 0.25 \times 0.12$ \\
\hline $2 \theta$ range $(\mathrm{deg})$ & $2.05-27.50$ & $1.96-27.50$ \\
\hline index ranges & $\begin{array}{l}-25 \leq h \leq 25 \\
-11 \leq k \leq 9 \\
-12 \leq l \leq 13\end{array}$ & $\begin{array}{l}-15 \leq h \leq 15 \\
-9 \leq k \leq 9 \\
-17 \leq l \leq 17\end{array}$ \\
\hline reflns collected & 13171 & 10153 \\
\hline independent reflns $\left[R_{\text {int }}\right]$ & $4141[0.0559]$ & $2424[0.0278]$ \\
\hline data/restraints/parameters & $4141 / 1 / 280$ & $2424 / 0 / 141$ \\
\hline GOF on $F^{2}$ & 1.093 & 1.073 \\
\hline final $\mathrm{R}$ indices $[I>2 \sigma(I)]$ & $\begin{array}{l}\mathrm{R} 1=0.0584, \\
\mathrm{wR} 2=0.1409\end{array}$ & $\begin{array}{l}\mathrm{R} 1=0.0480 \\
\mathrm{wR} 2=0.1286\end{array}$ \\
\hline $\mathrm{R}$ indices (all data) & $\begin{array}{l}\mathrm{R} 1=0.0653 \\
\mathrm{wR} 2=0.1452\end{array}$ & $\begin{array}{l}\mathrm{R} 1=0.0542 \\
\mathrm{wR} 2=0.1334\end{array}$ \\
\hline $\begin{array}{l}\text { largest diff. peak and hole } \\
\quad\left(\mathrm{e} \AA^{-3}\right)\end{array}$ & 1.491 and -1.032 & 0.438 and -0.344 \\
\hline
\end{tabular}

Table 2. Selected Bond Distances ( $\mathrm{A}$ ) and Angles (deg) for Complex 4 (esds in parentheses)

$\begin{array}{lclr}\mathrm{Cu}-\mathrm{O}(1) & 1.914(3) & \mathrm{Cu}-\mathrm{N}(1) & 2.018(4) \\ \mathrm{Cu}-\mathrm{O}(2) & 1.901(3) & \mathrm{Cu}-\mathrm{N}(2) & 2.033(4) \\ \mathrm{O}(1)-\mathrm{C}(4) & 1.359(6) & \mathrm{N}(1)-\mathrm{C}(2) & 1.284(6) \\ \mathrm{O}(2)-\mathrm{C}(11) & 1.353(6) & \mathrm{N}(2)-\mathrm{C}(9) & 1.270(7) \\ \mathrm{C}(2)-\mathrm{C}(3) & 1.511(7) & \mathrm{C}(3)-\mathrm{C}(4) & 1.554(7) \\ \mathrm{C}(9)-\mathrm{C}(10) & 1.518(7) & \mathrm{C}(10)-\mathrm{C}(11) & 1.545(7) \\ & & & \\ \mathrm{O}(1)-\mathrm{Cu}-\mathrm{O}(2) & 177.4(2) & \mathrm{O}(2)-\mathrm{Cu}-\mathrm{N}(1) & 87.35(15) \\ \mathrm{O}(1)-\mathrm{Cu}-\mathrm{N}(1) & 91.11(15) & \mathrm{O}(2)-\mathrm{Cu}-\mathrm{N}(2) & 91.41(16) \\ \mathrm{O}(1)-\mathrm{Cu}-\mathrm{N}(2) & 90.13(15) & \mathrm{N}(1)-\mathrm{Cu}-\mathrm{N}(2) & 178.75(17)\end{array}$

Table 3. Selected Bond Distances ( $\mathrm{A}$ ) and Angles (deg) for Complex 5 (esds in parentheses)

\begin{tabular}{cccc}
\hline $\mathrm{Cu}-\mathrm{O}(1)$ & $1.874(2)$ & $\mathrm{Cu}-\mathrm{N}(1)$ & $2.023(2)$ \\
$\mathrm{O}(1)-\mathrm{C}(4)$ & $1.358(3)$ & $\mathrm{N}(1)-\mathrm{C}(2)$ & $1.486(4)$ \\
$\mathrm{C}(2)-\mathrm{C}(3)$ & $1.504(5)$ & $\mathrm{C}(3)-\mathrm{C}(4)$ & $1.540(4)$ \\
$\mathrm{O}(1)-\mathrm{Cu}-\mathrm{O}(1 \mathrm{~A})$ & $163.93(16)$ & $\mathrm{O}(1)-\mathrm{Cu}-\mathrm{N}(1)$ & $95.51(9)$ \\
$\mathrm{O}(1)-\mathrm{Cu}-\mathrm{N}(1 \mathrm{~A})$ & $88.71(9)$ & $\mathrm{N}(1)-\mathrm{Cu}-\mathrm{N}(1 \mathrm{~A})$ & $149.53(14)$
\end{tabular}

\section{Synthesis and Characterization}

The copper CVD source reagents synthesized in this study consisted of a central $\mathrm{Cu}^{\mathrm{II}}$ metal ion coordinated by two fluorinated imino alcoholate or amino alcoholate chelates. The two electron-withdrawing $\mathrm{CF}_{3}$ groups on each of the free ligands are expected to increase the acidity of the adjacent hydroxyl group and, in turn, notably improve the stability as well as the volatility of the resulting complexes. On the basis of these considerations, we believe that our new design should provide a much needed improvement in stability compared with those of the nonfluorinated analogues, such as $\mathrm{Cu}\left[\mathrm{OCH}_{2} \mathrm{CH}_{2} \mathrm{NMe}_{2}\right]_{2}$ and $\mathrm{Cu}\left[\mathrm{OCHMeCH}_{2}-\right.$ $\left.\mathrm{NEt}_{2}\right]_{2}{ }^{9}$ The latter are well-known for their poor stability in

(9) Goel, S. C.; Kramer, K. S.; Chiang, M. Y.; Buhro, W. E. Polyhedron 1990, 9, 611. (b) Young, V. L.; Cox, D. F.; Davis, M. E. Chem. Mater. 1993, 5, 1701 . 


\section{Scheme 1}<smiles>CC(C)CC(C)(C)NON</smiles>

(1)

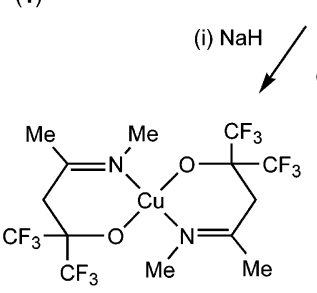

(4)

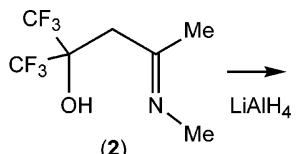
(2) (ii) $\mathrm{CuCl}_{2}$
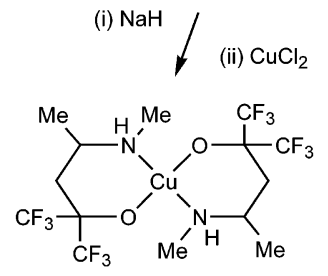

(5) air at room temperature and for their ability to produce highpurity copper metal by CVD at modest temperatures. ${ }^{10}$

The synthetic approach to the desired fluorinated imino alcohol and amino alcohol consists of three consecutive steps

$$
\left(\mathrm{CF}_{3}\right)_{2} \mathrm{C}=\mathrm{O}+\mathrm{Me}_{2} \mathrm{C}=\mathrm{O} \rightarrow\left(\mathrm{CF}_{3}\right)_{2} \mathrm{C}(\mathrm{OH}) \mathrm{CH}_{2} \mathrm{COMe}(\mathbf{1})
$$

$$
\text { (1) }+\mathrm{MeNH}_{2} \rightarrow\left(\mathrm{CF}_{3}\right)_{2} \mathrm{C}(\mathrm{OH}) \mathrm{CH}_{2} \mathrm{CMe}(=\mathrm{NMe})(\mathbf{2})
$$

(2) $+\mathrm{LiAlH}_{4} \rightarrow\left(\mathrm{CF}_{3}\right)_{2} \mathrm{C}(\mathrm{OH}) \mathrm{CH}_{2} \mathrm{CHMeNHMe} \mathrm{(3)}$

It is important to note that hexafluoroacetone trihydrate was deliberately used to replace anhydrous hexafluoroacetone in the first reaction. By making this modification, we avoided the use of anhydrous hexafluoroacetone, which is a suspected teratogenic reagent, and did not have any reduction in yield or other complications. Thus, our modified protocol is superior to the method originally reported in the literature ${ }^{11}$ and should be considered as the most satisfactory alternative for the preparation of the fluorinated keto alcohol. With the potential for further ligand functionalization, we fully expect that this method could generate a new class of anionic chelates showing metal-binding properties comparable to those of acetylacetonate or ketoiminates. ${ }^{12}$

This $\mathrm{CF}_{3}$-substituted keto alcohol was then converted into the related imino alcohol (2) and amino alcohol (3) via condensation with methylamine, followed by treatment with $\mathrm{LiAlH}_{4}$, respectively (Scheme 1). Subsequently, copper complexes $\mathbf{4}$ and $\mathbf{5}$ were synthesized using a method related to that used for the analogous complex $\mathrm{Cu}\left[\mathrm{OC}\left(\mathrm{CF}_{3}\right)_{2} \mathrm{CH}_{2}-\right.$ $\left.\mathrm{NH}_{2}\right]_{2},{ }^{11}$ involving a prior treatment of the imino alcohol (or amino alcohol) with excess $\mathrm{NaH}$ to generate the anionic ligand fragment, followed by the addition of a $\mathrm{CuCl}_{2}$ suspended in THF at room temperature. ${ }^{13}$ Vacuum sublimation and recrystallization were routinely used for the ultimate

(10) Hambrock, J.; Becker, R.; Birkner, A.; Weiss, J.; Fischer, R. A. Chem. Commun. 2002, 68. (b) Becker, R.; Devi, A.; Weiss, J.; Weckenmann, U.; Winter, M.; Kiener, C.; Becker, H.-W.; Fischer, R. A. Chem. Vap. Deposition 2003, 9, 149.

(11) Chang, I.-S.; Willis, C. J. Can. J. Chem. 1977, 55, 2465. (b) Loeb, S. J.; Richardson, J. F.; Willis, C. J. Inorg. Chem. 1983, 22, 2736.

(12) Tung, Y.-L.; Tseng, W.-C.; Lee, C.-Y.; Chi, Y.; Peng, S.-M.; Lee, G.-H. Organometallics 1999, 18, 864. (b) Chi, Y.; Hsu, P.-F.; Liu, C.-S.; Ching, W.-L.; Chou, T.-Y.; Carty, A. J.; Peng, S.-M.; Lee, G.H.; Chuang, S.-H. J. Mater. Chem. 2002, 12, 3541.

(13) Chang, C.-H.; Hwang, K. C.; Liu, C.-S.; Chi, Y.; Carty, A. J.; Scoles, L.; Peng, S.-M.; Lee, G.-H.; Reedijk, J. Angew. Chem., Int. Ed. 2001, $40,4651$.

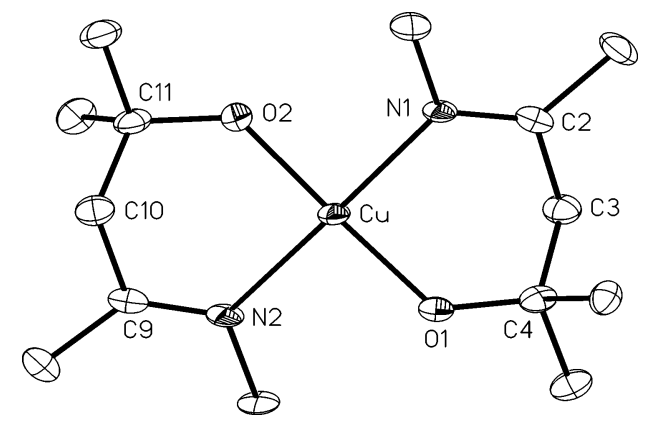

Figure 1. ORTEP drawing of complex 4 with thermal ellipsoids shown at the $50 \%$ probability level. All fluorine atoms are removed for clarity.

purification. It is notable that all these copper complexes are highly soluble in solvents such as $\mathrm{CH}_{2} \mathrm{Cl}_{2}$, THF, and acetone, and their stability in air is comparable to those of the closely related fluoroalkoxide complexes $\mathrm{Cu}(\mathrm{en})_{2}\left(\mathrm{OR}_{\mathrm{F}}\right)_{2}$ and $\mathrm{Cu}(\mathrm{py})_{2}\left(\mathrm{OR}_{\mathrm{F}}\right)_{2}$, where $\mathrm{OR}_{\mathrm{F}}=$ hexafluoroisopropoxo and hexafluoro-tert-butoxo group. ${ }^{14}$

A single-crystal $\mathrm{X}$-ray diffraction study on the imino complex, $\mathbf{4}$, was conducted to reveal its molecular structure in the solid state. As indicated in Figure 1, the $\mathrm{Cu}^{\mathrm{II}}$ metal center shows a planar coordination arrangement with a small dihedral angle of $2.1^{\circ}$, which is calculated using the leastsquares planes, $\mathrm{Cu}-\mathrm{O}(1)-\mathrm{N}(1)$ and $\mathrm{Cu}-\mathrm{O}(2)-\mathrm{N}(2)$, defined by the $\mathrm{Cu}$ metal atom as well as all donor atoms of each chelating ligand. The imino functional group is clearly identified by the short $\mathrm{C}-\mathrm{N}$ bond distances $(1.271-1.284$ $\AA$ ), which are similar to the $\mathrm{C}=\mathrm{N}$ distances observed in Schiff base metal complexes. ${ }^{15}$ The average $\mathrm{Cu}-\mathrm{N}$ distance $(\sim 2.020 \AA)$ is comparable to the $\mathrm{Cu}-\mathrm{N}$ distances observed in other complexes, $\left[\mathrm{Cu}(\mathrm{hfac})\left(\mathrm{OCH}_{2} \mathrm{CH}_{2} \mathrm{NMe}_{2}\right)\right]_{2}(2.020$ (5) $\AA)^{16}$ and $\mathrm{Cu}(\mathrm{hfac})_{2}\left(\mathrm{H}_{2} \mathrm{NBu}^{\mathrm{t}}\right)(1.992(4) \AA),{ }^{17}$ and is significantly longer than the $\mathrm{Cu}-\mathrm{O}$ distances observed within this molecule $(\sim 1.907 \AA)$ or anhydrous $\mathrm{Cu}(\mathrm{hfac})_{2}(1.91-1.92$ $\AA) .{ }^{18}$ Moreover, the imino alcoholate backbones are arranged in a chair conformation, with their unique methylene spacers residing on the opposite side of the $\mathrm{N}_{2} \mathrm{O}_{2}$ square plane. Similar to that of the many amino alcoholate complexes reported in the literature ${ }^{19}$ the $\mathrm{C}-\mathrm{C}$ distances adjacent to the alcoholate group $(\mathrm{C}(3)-\mathrm{C}(4)=1.554(7) \AA$ and $\mathrm{C}(10)-$ $\mathrm{C}(11)=1.545(7) \AA)$ are found to be notably longer than the other $\mathrm{C}-\mathrm{C}$ single bonds $(\mathrm{C}(2)-\mathrm{C}(3)=1.511(7) \AA$ and $\mathrm{C}(9)-\mathrm{C}(10)=1.518(7) \AA)$. This weakening of the $\mathrm{C}-\mathrm{C}$ bonding could assist in the spontaneous ligand fragmentation which occurs upon heating and could account for the ease of metal deposition.

For purposes of comparison, the X-ray diffraction study on $\mathbf{5}$ was also examined to reveal any possible effects of the saturated amino alcoholate ligand. As depicted in Figure 2,

(14) Jeffries, P. M.; Wilson, S. R.; Girolami, G. S. Inorg. Chem. 1992, 31, 4503.

(15) Luo, H.; Fanwick, P. E.; Green, M. A. Inorg. Chem. 1998, 37, 1127.

(16) Pinkas, J.; Huffman, J. C.; Bollinger, J. C.; Streib, W. E.; Baxter, D. V.; Chisholm, M. H.; Caulton, K. G. Inorg. Chem. 1997, 36, 2930.

(17) Woo, K.; Paek, H.; Lee, W. I. Inorg. Chem. 2003, 42, 6484.

(18) Maverick, A. W.; Fronczek, F. R.; Maverick, E. F.; Billodeaux, D. R.; Cygan, Z. T.; Isovitsch, R. A. Inorg. Chem. 2002, 41, 6488.

(19) Breeze, S. R.; Wang, S.; Chen, L. J. Chem. Soc. Dalton Trans. 1996, 1341. 
Lay et al.

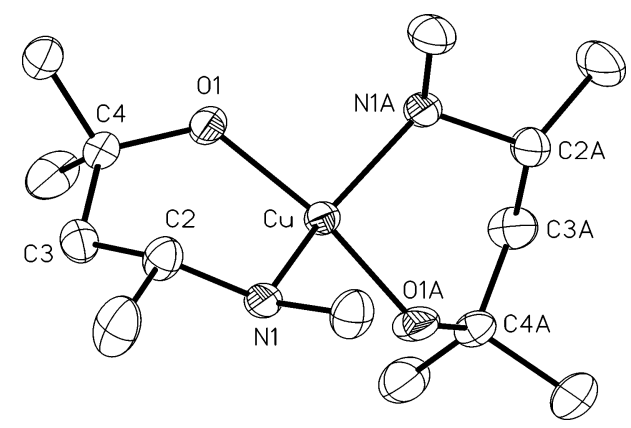

Figure 2. ORTEP drawing of complex 5 with thermal ellipsoids shown at the $25 \%$ probability level. All fluorine atoms are removed for clarity.

\section{Chart 1}
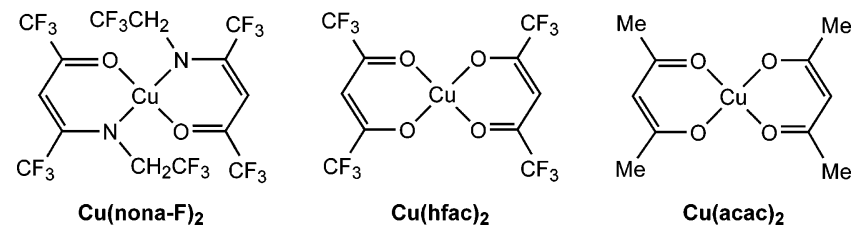

Table 4. Thermal Properties of the $\mathrm{Cu}^{\mathrm{II}}$ Precursors

\begin{tabular}{cccccc}
\hline compd & formula & $\mathrm{mp}$ & $T_{\mathrm{dec}}$ & $T_{1 / 2}{ }^{a}$ & wt $\%^{b}$ \\
\hline $\mathbf{4}$ & $\mathrm{Cu}\left[\mathrm{OC}\left(\mathrm{CF}_{3}\right)_{2} \mathrm{CH}_{2} \mathrm{C}(\mathrm{Me})=\mathrm{NMe}\right]_{2}$ & $152-153$ & 231 & 179 & 4.45 \\
$\mathbf{5}$ & $\mathrm{Cu}\left[\mathrm{OC}\left(\mathrm{CF}_{3}\right)_{2} \mathrm{CH}_{2} \mathrm{CHMeNHMe}\right]_{2}$ & $119-120$ & 277 & 196 & 0.62
\end{tabular}

${ }^{a}$ The temperature at which $50 \mathrm{wt} \%$ of the sample was lost during TG analysis. ${ }^{b}$ Residual wt $\%$ of the sample observed at $350{ }^{\circ} \mathrm{C}$.

this complex shows a slightly more distorted square-planar arrangement at the copper metal center. The average $\mathrm{Cu}-\mathrm{O}$ distance of $1.874 \AA$ is slightly shortened, while the $\mathrm{Cu}-\mathrm{N}$ distances of $2.023 \AA$ (av) remain relatively unchanged with respect to those of the previously examined complex 4 . Two methyl groups around the $\mathrm{C}-\mathrm{N}$ segment of each amino alcoholate chelate adopt the trans disposition. It can be seen that the fully saturated chelating ligand has caused an enlarged chelate bite angle $\left(95.51(9)^{\circ}\right.$ in $\mathbf{5}$ compared to $91.11(15)^{\circ}$ in 4 ) as well as a larger dihedral angle of $\sim 33^{\circ}$ between the chelating amino alcoholate ligands of $\mathbf{5}$. For comparison, a highly distorted square-planar configuration has also been observed in the ketoiminate complex $\mathrm{Cu}$ (nona$\mathrm{F})_{2}$, nona- $\mathrm{F}=\mathrm{CF}_{3} \mathrm{C}(\mathrm{O}) \mathrm{CHC}\left(\mathrm{NCH}_{2} \mathrm{CF}_{3}\right) \mathrm{CF}_{3}($ Chart 1$) .{ }^{20}$ In the latter case, the dihedral angle between the two planes defined by the ligands is twisted by $40^{\circ}$, showing a structural distortion possibly imposed by the $\mathrm{CF}_{3} \mathrm{CH}_{2}$ substituent on the nitrogen atom.

\section{CVD Studies}

Thermogravimetric (TG) analysis of both $\mathbf{4}$ and $\mathbf{5}$ shows a single-step weight loss pattern in the interval between 100$220{ }^{\circ} \mathrm{C}$ and leads to the formation of a dark-red lustrous residue under an argon atmosphere upon raising the temperature to $350{ }^{\circ} \mathrm{C}$. These thermal characteristics are listed in Table 4. It can be seen that the detected residual weights for both samples are much smaller than the theoretical wt $\%$ of the copper metal present in each individual sample

(20) Fine, S. M.; Dyer, P. N.; Norman, J. A. T.; Muratore, B. A.; Iampietro, R. L. Mater. Res. Soc. Symp. Proc. 1991, 204, 415.
Table 5. Deposition Parameters and the Analytical Data of Copper Thin Films ${ }^{a}$

\begin{tabular}{lclccrc}
\hline compd & $\begin{array}{c}T_{\text {sub }} \\
\left({ }^{\circ} \mathrm{C}\right)\end{array}$ & carrier & $\begin{array}{c}\text { thickness } \\
(\AA)\end{array}$ & $\begin{array}{c}\text { dep. rate } \\
(\AA / \mathrm{Am})\end{array}$ & $\begin{array}{r}\text { resistivity } \\
(\mu \Omega \mathrm{cm})\end{array}$ & $\begin{array}{c}\text { composition } \\
\mathrm{Cu} / \mathrm{C} / \mathrm{O}(\text { at. \%) }\end{array}$ \\
\hline $\mathbf{4}$ & 275 & $\mathrm{Ar}$ & 2363 & 157.5 & 4.27 & $84 / 13 / 4$ \\
$\mathbf{4}$ & 300 & $\mathrm{Ar}$ & 1912 & 127.5 & 19.46 & $71 / 23 / 6$ \\
$\mathbf{5}$ & 275 & $\mathrm{Ar}$ & 3040 & 202.7 & 17.02 & $74 / 24 / 2$ \\
$\mathbf{5}$ & 300 & $\mathrm{Ar}$ & 4540 & 302.7 & 101.59 & $51 / 41 / 8$ \\
$\mathbf{4}$ & 275 & $2 \% \mathrm{O}_{2}$ & 1360 & 90.7 & 4.89 & $87 / 9 / 4$ \\
$\mathbf{4}$ & 300 & $2 \% \mathrm{O}_{2}$ & 2318 & 154.5 & 8.76 & $86 / 9 / 5$ \\
$\mathbf{5}$ & 275 & $2 \% \mathrm{O}_{2}$ & 1882 & 125.5 & 2.77 & $93 / 5 / 2$ \\
$\mathbf{5}$ & 300 & $2 \% \mathrm{O}_{2}$ & 2481 & 165.4 & 2.87 & $92 / 5 / 3$ \\
$\mathbf{5}$ & 275 & $8 \% \mathrm{O}_{2}$ & 2641 & 176.1 & 1.98 & $95 / 4 / 1$ \\
$\mathbf{5}$ & 300 & $8 \% \mathrm{O}_{2}$ & 3599 & 239.9 & 2.11 & $96 / 3 / 1$ \\
$\mathrm{Cu}(\mathrm{hfac})_{2}$ & 275 & $2 \% \mathrm{O}_{2}$ & 2370 & 790 & 14.8 & $74 / 15 / 11$ \\
$\mathrm{Cu}(\mathrm{hfac})_{2}$ & 300 & $2 \% \mathrm{O}_{2}$ & 2690 & 867 & 10.6 & $83 / 6 / 11$
\end{tabular}

${ }^{a} T_{\text {sub }}$ represents the substrate temperature, and a $200 \AA$ layer of Pt was deposited onto the $\mathrm{Si}$ wafer to improve the copper deposition for experiments using $\mathrm{Cu}(\mathrm{hfac})_{2}$ as a source reagent.

( $\sim 11.8 \mathrm{wt} \%$ ), implying that direct volatilization, not sample decomposition, is the major process during TG analysis.

As both $\mathrm{Cu}^{\mathrm{II}}$ complexes $\mathbf{4}$ and $\mathbf{5}$ showed good volatility, we then started to investigate their chemical behavior by conducting copper CVD experiments. The first set of reactions was performed using source reagent $\mathbf{5}$ and argon carrier gas in the temperature range of $275-300^{\circ} \mathrm{C}$. Experimental parameters for the deposition of copper films on the Si (100) substrate are summarized in Table 5. For each of the CVD experiments, the source reagent $(\sim 250 \mathrm{mg})$ was vaporized at $80{ }^{\circ} \mathrm{C}$, with the carrier gas flow rate adjusted to $10-20 \mathrm{sccm}$ under a pressure of 1.5 Torr. Generally speaking, the films deposited at $275{ }^{\circ} \mathrm{C}$ showed slightly higher purity and lower resistivity than that obtained at 300 ${ }^{\circ} \mathrm{C}$. Subsequent XPS measurements indicated the incorporation of $\sim 24$ and $\sim 2$ at. \% of carbon and oxygen impurities even at $275{ }^{\circ} \mathrm{C}$, confirming that this source reagent is not very suitable for deposition of copper metal under an inert argon atmosphere. Similar behavior was confirmed for experiments using complex $\mathbf{4}$ as the CVD precursor.

To overcome this apparent obstacle, the deposition of copper was then conducted using a mixed argon gas containing $2 \% \mathrm{O}_{2}$ at temperatures of $250-325^{\circ} \mathrm{C}$. Generally speaking, the reactions conducted at the lower temperature of $250^{\circ} \mathrm{C}$ showed an insufficient rate of thin film formation, while at the higher temperature of $325^{\circ} \mathrm{C}$, the deposition of copper mainly occurred at the outlet of transport line, giving very small amounts of copper deposition on the substrate. This observation is consistent with the occurrence of rapid precursor decomposition in the gaseous phase. In contrast, the thin films deposited at 275 and $300{ }^{\circ} \mathrm{C}$ gave a red metallic luster and had excellent adhesion to the Si substrate. The SEM photos of these samples, depicted in Figures 3 and 4, exhibit the formation of densely packed microstructures with grain sizes proportional to the increase of deposition temperatures. For complex $\mathbf{5}$, it is notable that the thin film appeared to show the smallest grain sizes and surface roughness at $275{ }^{\circ} \mathrm{C}$, and then the grain sizes increased substantially at $300^{\circ} \mathrm{C}$. This observation suggests that the grain growth or the coalescence of grains becomes faster at higher temperatures, which then favors the formation of 

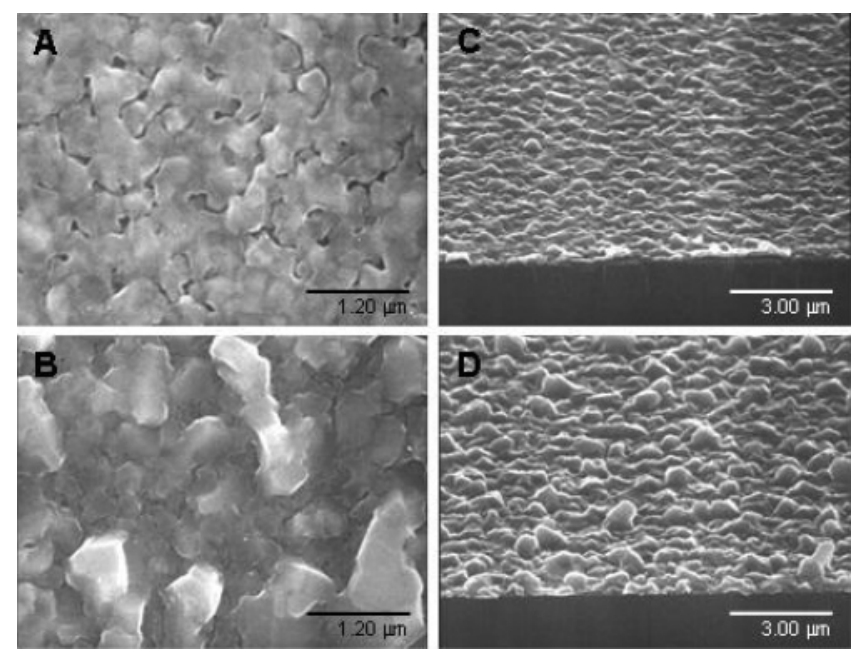

Figure 3. SEM images of copper film deposited from 4 using $2 \% \mathrm{O}_{2}$ in argon at (A) 275 and (B) $300{ }^{\circ} \mathrm{C}$; panels C and D depicted the tilt-view of $\mathrm{A}$ and $\mathrm{B}$, respectively.
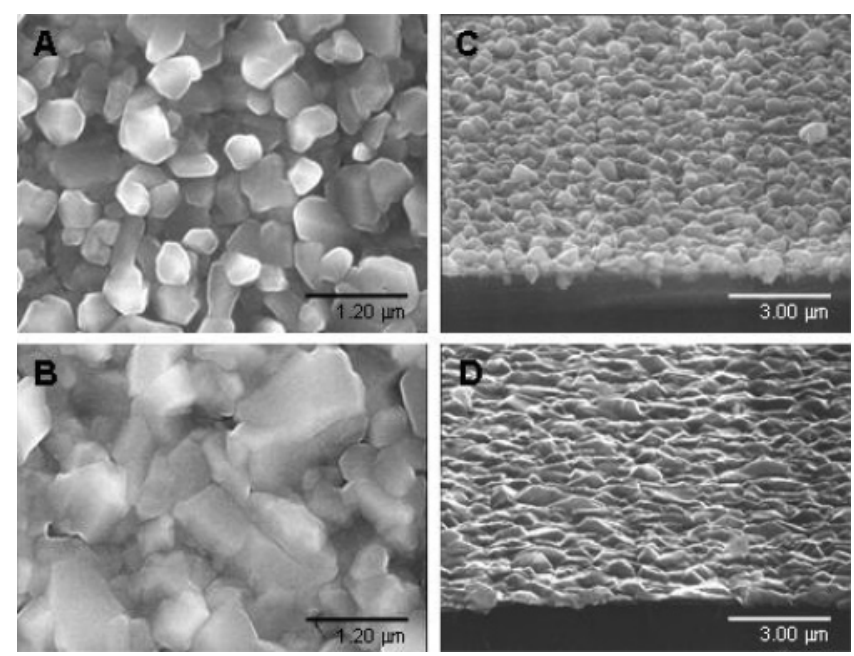

Figure 4. SEM images of copper film deposited from $\mathbf{5}$ using $2 \% \mathrm{O}_{2}$ in argon at (A) 275 and (B) $300{ }^{\circ} \mathrm{C}$; panels C and D depicted the tilt-view of $\mathrm{A}$ and $\mathrm{B}$, respectively.

larger metal particulates. ${ }^{21}$ Preliminary XPS analysis for films deposited using $\mathbf{4}$ as the source reagent shows the presence of $\geq 86 \%$ copper metal, along with approximately $9 \%$ carbon and $5 \%$ oxygen at $275-300{ }^{\circ} \mathrm{C}$; other impurities such as fluorine and nitrogen atoms were not observed during the XPS survey scan. For thin films deposited using source reagent 5 , the copper content increased to $92 \%$, while the carbon and oxygen impurities were reduced to 5\% and 3\%, respectively. In good agreement with the high purity, fourpoint probe measurements of this thin film gave a resistivity as low as $2.77 \mu \Omega \mathrm{cm}$, which is slightly higher than that of bulk copper metal $(1.7 \mu \Omega \mathrm{cm})$.

On the basis of the above observations, it is possible that the fully saturated amino alcoholate complex $\mathbf{5}$ would have an enhanced reactivity with respect to $\mathrm{O}_{2}$ in a mixed carrier gas. The proposed deposition mechanism consists of the $\mathrm{O}_{2^{-}}$

(21) Kim, D.-H.; Wentorf, R. H.; Gill, W. N. J. Electrochem. Soc. 1993 , 140, 3273. (b) Gladfelter, W. L. Chem. Mater. 1993, 5, 1372. (c) Lee, W.-J.; Min, J.-S.; Rha, S.-K.; Chun, S.-S.; Park, C.-O. J. Mater. Sci. Mater. Electron. 1996, 7, 111. (d) Semaltianos, N. G.; Pastol, J.-L.; Doppelt, P. Surf. Sci. 2004, 562, 157.

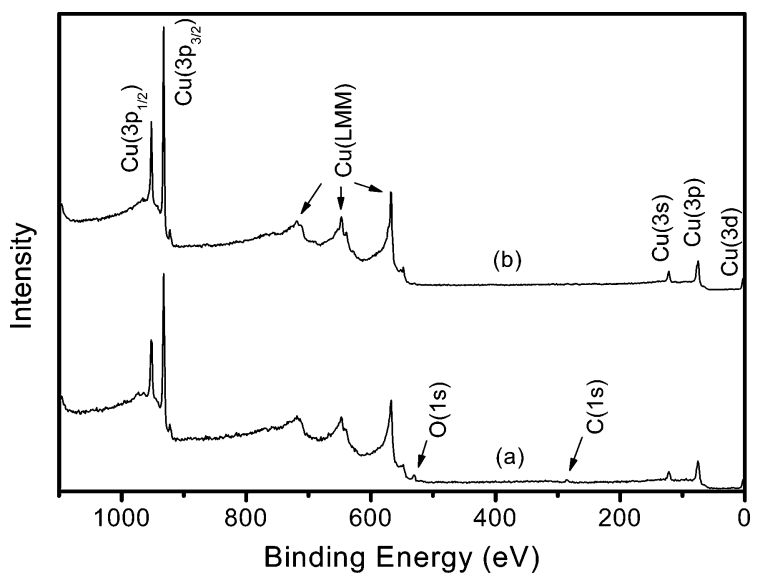

Figure 5. XPS spectra of the copper films deposited from 5 at $275{ }^{\circ} \mathrm{C}$ using (a) pure argon and (b) $2 \% \mathrm{O}_{2}$ in argon.

induced partial oxidation of the ligand. This reaction would deplete the $\mathrm{O}_{2}$ concentration in the carrier gas and result in effective copper deposition with reduced impurity content. The representative XPS spectra of the thin film samples deposited using 5 at $275{ }^{\circ} \mathrm{C}$ under inert argon and $2 \% \mathrm{O}_{2}$ in argon are shown in Figure 5. In addition to the signals derived from the copper, weak oxygen and carbon signals centered at 531.5 and $284.5 \mathrm{eV}$ can be seen in these spectra. Their atomic contents are then calculated using the integration area under each peak divided by their sensitivity factors.

The possible influence of supplementary $\mathrm{O}_{2}$ during the CVD experiments was further examined by increasing the relative proportion of $\mathrm{O}_{2}$ to $8 \%$ in argon. For the imino alcoholate complex 4, deposition of a dark brown coating was observed at the temperature interval of $275-300{ }^{\circ} \mathrm{C}$, for which the extremely high resistivities correspond to the formation of oxidized $\mathrm{CuO}$ or $\mathrm{Cu}_{2} \mathrm{O}$ coatings. On the other hand, high-quality copper films can be deposited on the $\mathrm{Si}$ substrate using the amino alcoholate chelate $\mathbf{5}$. As indicated in Table 5, the XPS and four-point probe analyses show that one thin film possesses the highest copper content of $\sim 96$ at. \% with the lowest resistivity among all the thin film samples obtained in this study. Again, the function of the amino alcoholate versus that of imino alcoholate remains uncertain, but it seems that the amino alcoholate ligand in $\mathbf{5}$ allows efficient consumption of supplementary $\mathrm{O}_{2}$ in the carrier gas; otherwise, the remaining $\mathrm{O}_{2}$ in carrier gas would react with the as-deposited copper, leading to the formation of oxidized materials such as $\mathrm{Cu}_{2} \mathrm{O}$ or $\mathrm{CuO}$ during $\mathrm{CVD}$ runs. ${ }^{22}$ This hypothesis is verified by a final increase of the $\mathrm{O}_{2} / \mathrm{Ar}$ ratio to $20 \%$, for which generation of metal oxides such as $\mathrm{Cu}_{2} \mathrm{O}$ and $\mathrm{CuO}$ was clearly obtained.

For further comparison, we performed the deposition using the commercially available $\mathrm{Cu}(\mathrm{hfac})_{2}$ reagent as well as the above-mentioned carrier gas. Interestingly, for the control experiments using a $\mathrm{Si}$ wafer as the substrate, no obvious thin film deposition was observed in the temperature range

(22) Condorelli, G. G.; Malandrino, G.; Fragalá, I. L. Chem. Vap. Deposition 1999, 5, 21. (b) Medina-Valtierra, J.; Ramirez-Ortiz, J.; Arroyo-Rojas, V. M.; Bosch, P.; de los Reyes, J. A. Thin Solid Films 2002, 405, 23. (c) Condorelli, G. G.; Malandrino, G.; Fragalá, I. Chem. Mater. 1994, 6, 1861. 

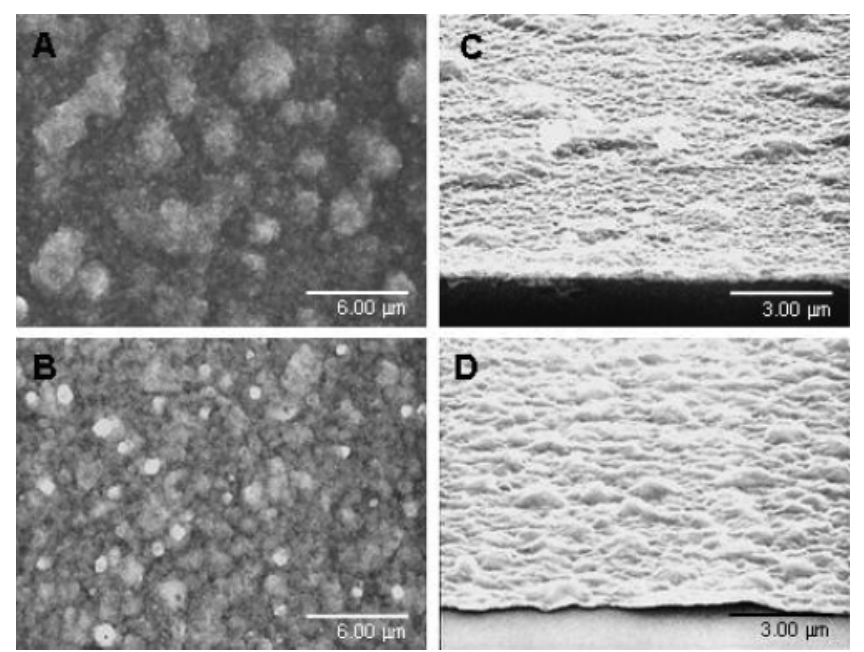

Figure 6. SEM images of copper film deposited from $\mathrm{Cu}(\mathrm{hfac})_{2}$ using $2 \% \mathrm{O}_{2}$ in argon at (A) 275 and (B) $300{ }^{\circ} \mathrm{C}$; panels $\mathrm{C}$ and $\mathrm{D}$ depicted the tilt-view of $\mathrm{A}$ and $\mathrm{B}$, respectively.

of $275-300{ }^{\circ} \mathrm{C}$, showing that $2 \% \mathrm{O}_{2}$ in argon is insufficient to initiate the anticipated copper deposition, despite the fact that pure copper metal free from carbon contamination was documented using $\mathrm{Cu}(\mathrm{acac})_{2}$ and a lower concentration of $\mathrm{O}_{2}$ partial pressure. ${ }^{23}$ This evidence confirmed that the $\mathrm{O}_{2-}$ induced copper deposition relied critically on the chemical reactivity of the source reagents. On the other hand, the growth of copper became much more facile upon switching the substrate from a Si wafer to a sputtered Pt film, which has been used as the preferred growth substrate for the $\mathrm{Cu}$ (hfac) $)_{2}$ source reagent. ${ }^{23}$ The XPS study showed that the level of purity appears to be inferior to those obtained in previous studies, while the SEM analysis indicated the formation of relatively smaller particulates with small voids and cracks at the grain boundaries (Figure 6). We speculated that this variation of surface morphology is most likely caused by changing the substrates, with the higher electrical conductivity of Pt metal compared with the less conductive dielectric surface such as $\mathrm{Si}$ or $\mathrm{SiO}_{2}$ lowering the deposition temperatures. ${ }^{24}$ Moreover, the high catalytic activity known for $\mathrm{Pt}$ metal could also enhance the surface reaction between the adsorbed copper reagents and $\mathrm{O}_{2}$, which would then reduce the barrier to the deposition and nucleation process, yielding smaller crystallites on the substrate.

\section{Discussion}

$\mathrm{Cu}^{\mathrm{II}}$-based complexes have been extensively used to produce high-purity copper-containing thin film materials using the CVD technique. This class of complexes includes fluorinated and nonfluorinated $\beta$-diketonates, Schiff base precursors, and amino alcoholate complexes: some representative structural drawings are depicted in Charts 1 and 2. It was thus anticipated that changing the ligand design might

(23) Condorelli, G. G.; Malandrino, G.; Fragalá, I. Chem. Mater. 1995, 7, 2096. (b) Hammadi, Z.; Lecohier, B.; Dallaporta, H. J. Appl. Phys. 1993, 73, 5213.

(24) Chiou, J.-C.; Juang, J.-C.; Chen, M.-C. J. Electrochem. Soc. 1995, 142, 177. (b) Kim, Y. S.; Kim, D. J.; Kwak, S. K.; Kim, E. K.; Min, S.-K.; Jung, D. Jpn. J. Appl. Phys. Part 2 1998, 37, L462.

\section{Chart 2}

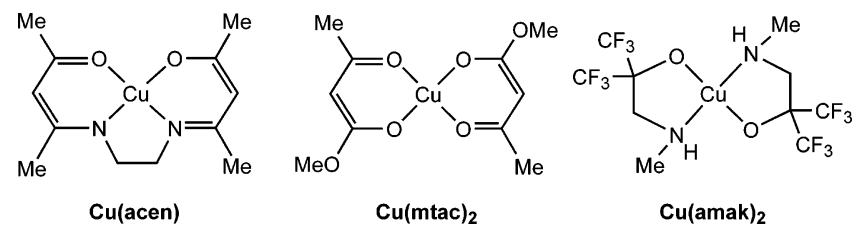

Scheme 2

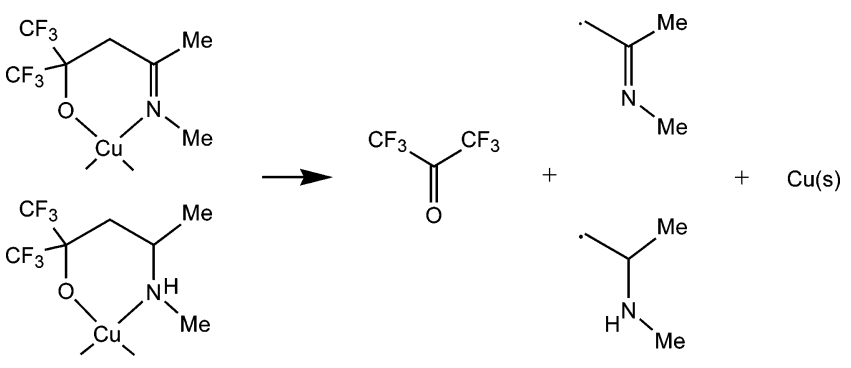

have a dramatic impact on the performance of these complexes for copper CVD studies.

The most intensively investigated source reagents in the literature are the $\beta$-diketonate complexes $\mathrm{Cu}(\mathrm{hfac})_{2}$ and $\mathrm{Cu}$ $(\mathrm{acac})_{2}$. For depositions conducted under an inert carrier gas, thermally induced ligand decomposition eventually occurs because of the higher reaction temperatures, resulting in anticipated copper films with a high level of contamination. In contrast, typical metal depositions are best conducted using $\mathrm{H}_{2}$ carrier gas to facilitate thermal reduction at the lower temperatures; while deposition conducted under high partial pressures of $\mathrm{O}_{2}$ leads to the formation of oxides $\mathrm{CuO}$ or $\mathrm{Cu}_{2} \mathrm{O}$ depending on the concentration ratio of $\mathrm{O}_{2}$ to the volatile $\mathrm{Cu}$ source, such as $\mathrm{Cu}$ (acen). ${ }^{25}$ Recently, a further variation was introduced by replacing the $\beta$-diketonate complexes with $\beta$-ketoesterates such as $\mathrm{Cu}(\mathrm{mtac})_{2}$ : the latter are known for their weaker metal-ligand bonding and higher tendency for the ligands to produce volatile organic species in a controllable manner. ${ }^{7 a, 26}$ Plasma-enhanced chemical vapor deposition (PECVD) studies have also been attempted to take advantage of the high reactivity of the ligands. ${ }^{27}$

With the above observations in mind, we argued that our imino alcoholate and amino alcoholate complexes $\mathbf{4}$ and $\mathbf{5}$ should display a conceptually related ligand dissociation and decomposition without the need for a reducing gas. This possibility was anticipated from our previous studies of the related amino alcoholate complex $\mathrm{Cu}($ amak) 2 , for which heating under an inert atmosphere facilitated copper metallization via a concomitant ligand decomposition to produce free amine and hexafluoroacetone. ${ }^{12 \mathrm{~b}, 28}$ Therefore, we believe that complexes $\mathbf{4}$ and $\mathbf{5}$ should be capable of depositing copper metal via related $\mathrm{C}-\mathrm{C}$ bond heterolysis at the nearby alcoholate unit, leading to the formation of hexafluoroacetone and associated radical fragments (Scheme 2). It was thus expected that trace amounts of $\mathrm{O}_{2}$ in the carrier gas would

(25) Condorelli, G. G.; Malandrino, G.; Fragalà, I. L. Chem. Vap. Deposition 1999, 5, 237.

(26) Hwang, S.; Choi, H.; Shim, I. Chem. Mater. 1996, 8, 981.

(27) Hwang, S. T.; Shim, I.; Lee, K. O.; Kim, K. S.; Kim, J. H.; Choi, G. J.; Cho, Y. S.; Choi, H. J. Mater. Res. 1996, 11, 1051

(28) Hsu, P.-F.; Chi, Y.; Lin, T.-W.; Liu, C.-S.; Carty, A. J.; Peng, S.-M. Chem. Vap. Deposition 2001, 7, 28. 
react with the dissociated organic radicals, suppressing hydrocarbon contamination on the substrate. Finally, among the reaction byproducts collected using a liquid $\mathrm{N}_{2}$ cold trap, only hexafluoroacetone and trace amounts of the chelating ligands could be identified using ${ }^{19} \mathrm{~F}$ NMR analysis, providing preliminary support for our mechanistic delineation.

\section{Summary}

Two complexes, $\mathbf{4}$ and $\mathbf{5}$, in the copper $2+$ oxidation state were prepared and studied as possible precursors for the fabrication of copper thin films by thermal CVD methods. In contrast to previously described $\mathrm{Cu}^{\mathrm{II}} \mathrm{CVD}$ precursors, they proved to be easily purified, showed a greater stability at lower temperatures, and can be cleanly converted to copper metal in the temperature range of $275-300{ }^{\circ} \mathrm{C}$, making them very suitable source reagents for depositing copper via the CVD method.

The copper thin films were deposited using both pure argon and low concentrations of $\mathrm{O}_{2}(2-8 \%)$ in argon as the carrier gas. The mixing of $\mathrm{O}_{2}$ in the argon carrier gas seems to have the desirable effect of increasing the purity and

(29) Zhang, Y.; Choi, S. W.-K.; Puddephatt, R. J. J. Am. Chem. Soc. 1997, 119, 9295. (b) Chen, Y.-L.; Liu, C.-S.; Chi, Y.; Carty, A. J.; Peng, S.-M.; Lee, G.-H. Chem. Vap. Deposition 2002, 8, 17. (c) Aaltonen, T.; Alen, P.; Ritala, M.; Leskela, M. Chem. Vap. Deposition 2003, 9 , 45 . lowering the resistivity of the deposited films. This result shows that low concentrations of $\mathrm{O}_{2}$ in carrier gas solve both of the problems associated with greater impurities and inevitable metal oxidation. Although such a deposition strategy has been widely applied to noble metal elements such as $\mathrm{Ru}, \mathrm{Pd}, \mathrm{Ir}$, and $\mathrm{Pt},{ }^{29}$ there is only a few precedences for application to $\mathrm{Cu}$ metal deposition, ${ }^{23}$ for which metal oxidation is expected to occur rapidly at elevated temperatures. The exact roles of oxygen in these experiments are not fully understood; however, because of its low concentration, ongoing ligand oxidation may completely deplete the oxygen present, which would then lower the possibility of copper oxidation. Finally, our success in depositing copper under such a low concentration of $\mathrm{O}_{2}$ implies that the same approach could also be suitable for advanced techniques, such as atomic layer deposition (ALD), and pave the way to the growth copper thin films by ALD using these $\mathrm{Cu}^{\mathrm{II}}$ source reagents under a well-controlled oxidative environment.

Acknowledgment. We would like to thank the National Science Council of Taiwan for Grant NSC 93-2113-M-007011.

Supporting Information Available: X-ray crystallographic data file (CIF) of complexes $\mathbf{4}$ and $\mathbf{5}$. This material is available free of charge via the Internet at http://pubs.acs.org.

IC050845H 